\title{
Letter to the Editor: Bacterial Flora and Ion Content of Cystic Fibrosis Sputum
}

\author{
J. P. KILBOURN
}

3178 S. W. Fairmount Blvd., Portland, Oregon, USA

Sir:

In 1968, Burns and May (2) presented a hypothesis for the pattern for the bacteriology of cystic fibrosis. In 1972, May et al. (12) suggested that contrary to the classical hypothesis children with cystic fibrosis are susceptible from birth to infection of the lower respiratory tract, not only by Staphylococcus aureus, but also by other respiratory pathogens to which they may be exposed.

In 1968, Kilbourn et al. (11) presented a method for quantitating bacterial flora in sputum. The hypothesis of Burns and May was substantiated by performing quantitation of bacterial flora in sputum from 20 patients with cystic fibrosis over a period of 10 years $(9,10)$. Høiby (5) conducted an epidemiologic investigation of the respiratory tract bacteriology in patients with cystic fibrosis and concluded that although many species may colonize the respiratory tracts of these patients, the main clinical problems concern Pseudomonas aeruginosa and $S$. aureus.

The consistency of the sputum produced by most patients with cystic fibrosis is one striking feature of the disease. This sputum is not easily liquified, and one suggestion for its consistency was the ionic composition. Unfortunately, the data currently available are in disagreement $(4,13)$. Preliminary data, obtained on the sputum from 16 patients with cystic fibrosis, has shown what appears to be a relationship between the ionic composition $\left(\mathrm{Na}^{+}, \mathrm{K}^{+}, \mathrm{Ca}^{2+}\right.$, and $\mathrm{Cl}^{-}$) and the bacterial sputum groups suggested by Burns and May (10).

This is a report on quantitation of ions and bacterial flora in multiple sputum specimens from 16 patients with cystic fibrosis and from 12 patients with lung cancer.

Fourteen of sixteen patients with cystic fibrosis were selected for this study because: (1) they were able to cough up at least 0.2 $\mathrm{ml}$ of purulent sputum without postural drainage or after only brief physical therapy; (2) they were in a relatively stable clinical condition and did not require hospitalization, but no effort was made to group them as to their chemotherapy; (3) their sputum bacterial flora could be placed in one of the bacterial sputum groups suggested by Burns and May (2). Patients with cystic fibrosis who did not have one of the bacterial sputum groups suggested by Burns and May were not included in this study. None of the patients included in this study were found to have Streptococcus pneumoniae or Group A beta hemolytic Streptococcus. This could be due to the fact that the patients were not "clinically sick" but were seen as outpatients at the Cystic Fibrosis Clinic of the University of Oregon Health Sciences Center or were attending the Cystic Fibrosis Summer Camp (3).

The two additional patients with cystic fibrosis who were included in this study were hospitalized for pneumonia during this study, and the sputum specimens were obtained and examined during their hospitalization.

Sputum was obtained by transtracheal aspiration from 12 adult male patients (greater than 52 years old) with lung cancer, seen at the Veterans Administration Hospital, Portland, OR. These patients were in stable condition without obvious signs of pulmonary infection, and the transtracheal aspirate was obtained prior to surgery for removal of cancerous lung tissue (1).

All sputum specimens were collected in sterile containers, and the volume was noted. A known volume of sterile water was added to the sputum container, and the mixture was vigorously agitated until the sputum was homogenized. Serial dilutions of the sputum: water mixtures were made, and agar media was inoculated so as to obtain quantitative colony counts. Colony-forming units $/ \mathrm{ml}$ of

Table 1

\begin{tabular}{|c|c|c|c|c|c|c|c|}
\hline \multirow{2}{*}{$\begin{array}{l}\text { No. of pa- } \\
\text { tients }\end{array}$} & \multirow{2}{*}{$\begin{array}{c}\text { Sputa/pa- } \\
\text { tient }\end{array}$} & \multirow[b]{2}{*}{ Clinical disease } & \multirow[b]{2}{*}{ Clinical condition } & \multirow[b]{2}{*}{ Bacterial flora' } & \multicolumn{3}{|c|}{ Mean concentration (mmoles $/ \mathrm{ml}$ ) } \\
\hline & & & & & $\mathrm{Ca}^{2+}$ & $\mathrm{Na}^{+}$ & $\mathbf{K}^{+}$ \\
\hline 2 & 2 & $\begin{array}{l}\text { Cystic fibro- } \\
\text { sis }\end{array}$ & Stable & S. aureus only & 0.0022 & 0.100 & 0.045 \\
\hline 1 & 2 & $\begin{array}{l}\text { Cystic fibro- } \\
\text { sis }\end{array}$ & Stable & $\begin{array}{l}S . \text { aureus and } H . \text { in- } \\
\text { fluenzae }\end{array}$ & 0.00067 & 0.075 & 0.026 \\
\hline 3 & 2 & $\begin{array}{l}\text { Cystic fibro- } \\
\text { sis }\end{array}$ & Stable & P. aeruginosa only & 0.0013 & 0.087 & 0.032 \\
\hline 2 & 4 & $\begin{array}{l}\text { Cystic fibro- } \\
\text { sis }\end{array}$ & Stable & $P$. aeruginosa only & 0.0015 & 0.103 & 0.029 \\
\hline 1 & 2 & $\begin{array}{l}\text { Cystic fibro- } \\
\text { sis }\end{array}$ & Pneumonia & $\begin{array}{c}S . \text { aureus and } P . \\
\text { aeruginosa }\end{array}$ & 0.0013 & 0.055 & 0.034 \\
\hline 1 & 3 & $\begin{array}{l}\text { Cystic fibro- } \\
\text { sis }\end{array}$ & Pneumonia & $\begin{array}{l}H . \text { influenzae and } P . \\
\text { aeruginosa }\end{array}$ & $0.0000^{2}$ & 0.020 & 0.010 \\
\hline 12 & 1 & Lung cancer & Stable & $\begin{array}{l}\text { Upper respiratory } \\
\text { tract }\end{array}$ & 0.0001 & & 0.002 \\
\hline
\end{tabular}

'Only potential pathogens are reported here. Normal upper respiratory tract bacterial flora consisting of alpha hemolytic streptococcus and Neisseria and/or Branhamella species were also frequently isolated.

${ }^{2}$ No calcium ions were detected by SMAC or Corning model 940 Calcium Analyzer. 
Table 2

\begin{tabular}{|c|c|c|c|c|c|c|c|c|c|}
\hline \multirow[b]{2}{*}{ No. of patients } & \multirow{2}{*}{$\begin{array}{c}\text { No. of sputa/ } \\
\text { each bacterial } \\
\text { flora }\end{array}$} & \multirow[b]{2}{*}{ Bacterial Flora } & \multicolumn{3}{|c|}{$\begin{array}{l}\text { Mean concentration (nmmole/ } \\
\mathrm{ml} \text { ) }\end{array}$} & \multirow[b]{2}{*}{ Bacterial flora } & \multicolumn{3}{|c|}{$\begin{array}{c}\text { Mean concentration (mmole/ } \\
\mathrm{ml} \text { ) }\end{array}$} \\
\hline & & & $\mathrm{Ca}^{2+}$ & $\mathrm{Na}^{+}$ & $\mathrm{K}^{+}$ & & $\mathrm{Ca}^{2+}$ & $\mathrm{Na}^{+}$ & $\mathbf{K}^{+}$ \\
\hline 1 & $2 / 2$ & S. aureus only & 0.0021 & 0.074 & 0.015 & $\begin{array}{l}\text { S. aureus and } H . \text { in- } \\
\text { fluenzae }\end{array}$ & 0.0027 & 0.060 & 0.018 \\
\hline 1 & $1 / 1$ & S. aureus only & 0.0015 & 0.075 & 0.028 & $\begin{array}{l}S . \text { aureus and } P \text {. } \\
\text { aeruginosa }\end{array}$ & 0.0001 & 0.056 & 0.021 \\
\hline 1 & $1 / 1$ & S. aureus only & 0.0040 & 0.090 & 0.034 & $P$. aeruginosa only & 0.0044 & 0.130 & 0.064 \\
\hline 1 & $1 / 1$ & $\begin{array}{l}S . \text { aureus and } P \text {. } \\
\text { aeruginosa }\end{array}$ & 0.0026 & 0.135 & 0.037 & P. aeruginosa only & 0.0030 & 0.096 & 0.031 \\
\hline 1 & $1 / 2$ & $\begin{array}{l}\text { S. aureus and } P . \\
\text { aeruginosa }\end{array}$ & 0.0005 & 0.160 & 0.028 & P. aeruginosa only & 0.0009 & 0.052 & 0.021 \\
\hline 1 & $1 / 2$ & $\begin{array}{l}S . \text { aureus and } P \text {. } \\
\text { aeruginosa }\end{array}$ & 0.0010 & 0.040 & 0.018 & $P$. aeruginosa only & 0.0019 & 0.082 & 0.029 \\
\hline
\end{tabular}

sputum of the various organisms on sheep blood agar and chocolate agar are reported.

The liquified sputum:water mixture was analyzed for the quantity of the following ions: sodium, potassium and calcium, using the Sequential Multiple Analyzer Computer (SMAC) at Physicians Medical Laboratories, Portland, OR. The quantity of sodium, potassium, and calcium in sputum was found to be less than the serum specimens usually analyzed in the SMAC. In those cases where the SMAC indicated the sputum sample did not contain any sodium, potassium, and calcium, the sputum samples were reanalyzed manually at Miracle Medical Laboratories, Portland, $O R$.

The sodium and potassium were analyzed at Miracle Medical Laboratories on the IL 143 solid-state, direct-reading flame photometer using lithium as an internal standard. The calcium was analyzed at Miracle Medical Laboratory on the Corning model 940 calcium analyzer by complexometric titration. Sodium, potassium, and calcium quantities are reported per $\mathrm{ml}$ of sputum rather than per mg of protein, albumin, or globulin because both the SMAC and Miracle Medical Laboratory could find little protein, albumin, or globulin in the sputum specimens. It is possible that the protein, albumin, or globulin could have been destroyed due to the vigorous homogenization of the sputum specimens.

Table 1 lists the mean concentration of ions from multiple sputum specimens from individual patients with cystic fibrosis and the same bacterial flora in all specimens. Also reported is the mean concentration of ions from 12 sputa from 12 patients with lung cancer. No single pathogenic bacterial flora type predominated in the sputa from patients with lung cancer (1).

Table 2 reports the mean concentration of ions from multiple sputum specimens from individual patients with cystic fibrosis and a changing sputum bacterial flora pattern. The changes were from $S$. aureus only or $S$. aureus and $P$. aeruginosa to $S$. aureus and Hemophilus influenzae, $S$. aureus, and $P$. aeruginosa or $P$. aeruginosa only. These changes in bacterial flora are the ones predicted by the hypothesis of Burns and May (2).

Earlier, it was reported that the sputum bacterial flora of patients seen at the Veterans Administration Hospital, Portland, OR was different from that of patients with cystic fibrosis (6-8). In Table 1, there appears to be a difference in the ion concentration in sputum from patients with lung cancer compared to those with cystic fibrosis. Also, the sputum bacterial flora and ion concentration in sputum from patients with cystic fibrosis may be correlated in some way. At this time, there is not sufficient data to determine whether the bacteria cause a change in ion concentration or whether the ion concentration in the sputum selects for colonization by certain bacteria.

\section{REFERENCES AND NOTES}

I. Bruya, T. E., Haas, H., Kilbourn, J., and Morris, J.: Upper Airway Bacteria as a predictor of increased morbidity or mortality post-operatively and comparison of sputum and transtracheal aspirate with resected pulmonary parenchymal bacteria. Abstract submitted to the American Thoracic Society, 1979.

2. Burns, M. W., and May, J. R.: Bacterial precipitants in serum of patients with Cystic Fibrosis, Lancet, 1: 270 (1968).

3. Campbell, R. A:, Grach, J. L., Buxton, S., and Kilbourn, P.: C/F Kids make good campers-The congenitally malformed XV. Northwest Med., 67: 458 (1968).

4. Chernick, W. S., and Barbero, G. J.: Composition of tracheobronchial secretions in cystic fibrosis of the pancreas and bronchiectasis. Pediatrics. 24: 739 (1959).

5. Høiby, N.: Epidemiological investigations of the respiratory tract bacteriology in patients with cystic fibrosis. Acta Pathol. Microbiol. Scand. Sect. B Microbiol. Immunol., 82: 541 (1974).

6. Kilbourn, J. P.: Infection in cystic fibrosis. Lancet, 2: 878 (1970).

7. Kilbourn, J. P.: Infection in cystic fibrosis, Lancet, $l: 1243$ (1972)

8. Kilbourn, J. P.: Streptococcus pneumoniae in Chronic Bronchitis. Lancet, 1: 1009, (1973).

9. Kilbourn. J. P.: Cystic fibrosis. Lancet, l: 405 (1974)

10. Kilbourn, J. P.: Bacterial content and ionic composition of sputum in cystic fibrosis. Lancet, I: 334 (1978).

11. Kilbourn, J. P., Campbell, R. A., Grach, J. L., and Willis, M. D.: Quantitative bacteriology of sputum. Am. Rev. Respir. Dis., 98: 810 (1968).

12. May, J. R. Herrick, N. C., and Thompson. D.: Bacterial infection in cystic fibrosis. Arch. Dis. Child., 47: 908 (1972).

13. Potter, J. L., Matthews, L. W., Spector, S., and Lemm, J.: Studies on pulmonary secretions II. Osmolality and the ionic environment of pulmonary secretions from patients with cystic fibrosis, bronchiectasis and laryngectomy. Am. Rev. Respir. Dis., 96: 83 (1967). 